13. Бобринский А.А. Гончарство Восточной Европы. Источники и методы изучения. М.: Наука. 1978. $272 \mathrm{c}$.

14. Васильева И.Н. О выделении камского ареала гончарных традиций эпохи неолита // Археология, этнография и антропология Евразии. 2013. № 4. C. $73-83$.

15. Васильева И.Н. Ранненеолитическое гончарство Волго-Уралья (по материалам елшанской культуры) // Археология, этнография и антропология Евразии. 2011. № 2. С. 70-81.

16. Выборнов А.А. Неолит Волго-Камья. Самара: Изд-во СамГПУ, 2008. 490 с.
17. Лычагина Е.Л. Использование историко-культурного подхода для анализа неолитической керамики Прикамья // Традиции и инновации в изучении древнейшей керамики: мат-лы междунар. конфер. СПб.: ИИМК РАН, 2016. С. 113-115.

18. Лычагина Е.Л. Итоги радиоуглеродного датирования неолитических памятников Верхнего и Среднего Прикамья // Самарский научный вестник. 2014. № 4. C. 80-83.

Статья публикуется при поддержке гранта РГНФ: проект № 17-11-59004а/У «Неолитизация Верхнего и Среднего Прикамья: основные подходы и методы исследования".

\title{
EARLY CERAMIC COMPLEXES OF VOLGO-KAMA CULTURE (LYOVSHINO SITE CASE STUDY)
} (C) 2017

Lychagina Evgenia Leonidovna, candidate of historical sciences, associate professor of Ancient and Middle History of Russia Department

Batueva Nadezhda Sergeevna, master student of Ancient and Middle History of Russia Department Perm State Humanitarian Pedagogical University (Perm, Russian Federation)

Abstract. Lyovshino site was the first Neolithic settlement discovered on the territory of the Upper and Middle Kama. Its research was carried out in the 1920-30s. N.A. Prokoshev found weakly ornamented and non-ornamented pottery during excavations in 1934. Now, these potteries are considered as related to the early stage of the VolgoKama culture.

We conducted a technical and technological analyses of fragments of 10 vessels of the Lyovshino site. The results of the technical and technological analyses of weakly ornamented and non-ornamented pottery of the Lyovshino site are presented in the article. Pottery has very old AMS-dates (7748 \pm 51 and $7610 \pm 40 \mathrm{BP})$. These dates are synchronous to elshanskaya culture age. We consider that in the formation of ceramic complex of the Lyovshino site two components took part. The first can be related to second pottery group of elshanskaya culture; the sources of the second need additional studies.

Keywords: Upper and Middle Kama; Middle Volga; Neolithic; elshanskaya culture; Volgo-Kama culture; ceramic complexes; historical and cultural approach; radiocarbon analysis; initial plastic raw material; molding mass.

УДК 902, 903, 023

Статья поступила в редакцию 17.05.2017

\section{ГОНЧАРНАЯ ТЕХНОЛОГИЯ РАННЕНЕОЛИТИЧЕСКОГО НАСЕЛЕНИЯ ПОДОНЬЯ}

(C) 2017

Васильева Ирина Николаевна, кандидат исторических наук,

старший научный сотрудник научно-исследовательской части

Самарский государственный социально-педагогический университет (2. Самара, Российская Федераиия)

Аннотация. В статье публикуются результаты изучения гончарной технологии ранненеолитического населения Нижнего, Среднего и Верхнего Подонья. Данное исследование является составной частью многолетнего изучения древнейшей гончарной технологии населения восточноевропейской территории РФ, которое проводится в рамках историко-культурного подхода по методике А.А. Бобринского. Оно базируется на бинокулярной микроскопии, трасологии и эксперименте в виде физического моделирования. Технико-технологическому анализу было подвергнуто 483 образца керамики (условно отдельных сосудов). Они происходят из культурных слоев стоянки Ракушечный Яр (294 обр.) и I Раздорской стоянки (4 обр.), расположенных в Нижнем Подонье, а также 14 стоянок Среднего и Верхнего Подонья, содержащих керамику карамышевского типа (185 обр.). На основе полученных результатов в статье дается общая характеристика ранненеолитического гончарства разных регионов Подонья и итоги сравнительного анализа данных по гончарной технологии населения, с одной стороны, Нижнего, с другой - Среднего и Верхнего Подонья. Рассматриваются вопросы происхождения и распространения ранненеолитических гончарных традиций, выделяются черты сходства и различия процесса неолитизации в Подонье и Поволжье.

Ключевые слова: Подонье; ранний неолит; неолитизация; ракушечноярская культура; карамышевская культура; керамика; гончарная технология; бинокулярная микроскопия; трасология; эксперимент; происхождение гончарства; культурные традиции; культурогенез.

Исследование гончарной технологии ранненеолитического населения Подонья осуществлено в рамках историко-культурного подхода, разработанного А.А. Бобринским [1; 2]. Гончарная технология включает всю совокупность материалов, приемов и средств превращения пластичного сырья в готовые изделия. Основными задачами исследования являются реконструкция культурных традиций в древнем гончарстве и привлечение полученной информации к разработке проблем неолитизации изучаемого региона. Методика базируется на бинокулярной микроскопии, трасологии и эксперименте. Данная работа 
является составной частью многолетнего изучения древнейшей гончарной технологии населения восточноевропейской территории РФ, которое проводится по единой методике. К настоящему времени накоплена источниковая база данных технико-технологического анализа более 4 тысяч образцов (отдельных сосудов) из нео-энеолитических памятников Поволжья и сопредельных регионов. На ее основе составлена общая характеристика неолитического гончарства, выявлены центры зарождения ранненеолитического гончарства, тенденции развития и динамика распространения древнейших гончарных традиций [3-9]. Важным результатом проведенного исследования является определение наиболее общих критериев в изучении неолитической гончарной технологии. К ним относятся представления об исходном пластичном сырье и рецептура формовочных масс. Выбор этих элементов гончарной технологии в качестве основных обусловлен следующими обстоятельствами. Во-первых, наше исследование базируются на гипотезе А.А. Бобринского о возникновении гончарства [2]. Суть ее в том, что в «очагах» зарождения гончарства существовал длительный догончарный период, в течение которого для изготовления емкостей использовались органические и другие глиноподобные природные пластические материалы (илы). Возникновение традиций использования разных видов пластичного сырья зависело от природноклиматических и хозяйственных условий. Изделия из этого сырья не обжигались, а высушивались и применялись для хранения и переноски продуктов. По мнению А.А. Бобринского, эволюционное развитие гончарных традиций шло по пути добавления в органическую массу глины в качестве примеси и постепенного увеличения ее доли. По нашему мнению, вектор развития сырьевой базы гончарства в Поволжье был следующим: илы - илистые глины - глины. Параллельно происходило совершенствование технологии обжига: от очень низких температур (до $\left.450^{\circ}\right)$ - к низким (менее $650^{\circ}$ ), а затем к температурам каления (выше 650-750 ). Данная гипотеза позволяет разрабатывать проблему происхождения гончарства на основе изучения конкретной ранненеолитической керамики и особенностей процесса зарождения взглядов древнего населения на природные пластические материалы как сырье для изготовления емкостей. Различия видов этих материалов могут указывать на принадлежность ранненеолитических гончарств к разным очагам. Во-вторых, получение информации о навыках труда на этих ступенях гончарной технологии возможно по всем анализируемым образцам (в отличие от конструирования или формообразования), поэтому она приобретает статистическое значение. В-третьих, взгляды гончаров на пластичное сырье относятся к наиболее устойчивым элементам гончарной технологии, к группе субcmpaтных навыков, которые даже в условиях смешения разных в культурном отношении групп населения остаются неизменными очень долго [2]. Таким образом, результаты их изучения можно привлекать для разработки проблем как эволюционного развития неолитического гончарства, так и истории сложения населения, его культурогенеза.

Применение единой системы выделения, учета и сравнительного изучения по керамике данных о гон- чарной технологии и накопленная источниковая база позволили обратиться к исследованию ранненеолитического гончарства крупнейшего региона Восточной Европы - бассейна р. Дон. На современном уровне изучения археологических памятников и накопления радиоуглеродных дат к раннему неолиту в Нижнем Подонте относятся стоянки ракушечноярской культуры, а в Среднем и Верхнем Подонье стоянки карамышевской культуры. Технико-технологическому анализу было подвергнуто 483 образца керамики. Они происходят из культурных слоев стоянки Ракушечный Яр (294 обр.) и I Раздорской стоянки (4 обр.), расположенных в Нижнем Подонье, а также 14 стоянок Среднего и Верхнего Подонья, содержащих керамику карамышевского типа (185 обр.).

Результаты изучения способов изготовления ранненеолитической керамики Подонья изложены ниже в соответствии со стадиями гончарного производства: подготовительной, созидательной, закрепительной [2]. Полнота сведений о них напрямую зависит от степени сохранности сосудов. Специфика керамического материала неолитических стоянок (как правило, отсутствие целых сосудов и измельченность фрагментов) обусловливает получение наиболее полной технологической информации по подготовительной стадии гончарного производства, поэтому этому блоку данных уделено наибольшее внимание. Для характеристики созидательной стадии удалось реконструировать наиболее общие приемы изготовления сосудов. Заключения по закрепительной стадии соответствуют современному уровню разработанности методики.

\section{Нижнее Подонье}

Стоянка Ракушечный Яр расположена на острове Поречный, в русле р. Дон, близ станицы Раздорская. Автор раскопок стоянки Т.Д. Белановская выделила 23 культурных слоя, из которых слои 9-23 были отнесены к раннему неолиту [10]. Для неолитического керамического комплекса характерны плоскодонные сосуды баночной и горшковидной формы, в нижних слоях преимущественно без орнамента, а также орнаментированные прочерченным и накольчатым орнаментом [10, с. 96-123].

C помощью бинокулярного микроскопа было изучено 294 фрагмента верхних и придонных частей разных сосудов практически из всех стратиграфических слоев стоянки Ракушечный Яр, включая верхние, относящиеся к энеолиту. С целью установления верхней границы существования ранненеолитических гончарных традиций в статье используются данные и по энеолитической керамике. Ниже представлена общая характеристика гончарной технологии неолитического населения стоянки.

Подготовительная стадия. В рамках данной стадии рассматриваются вопросы о виде и характере исходного пластичного сырья (ИПС), источниках добычи этого сырья, способах его подготовки и рецептах составления формовочных масс (ФМ). К настоящему времени в результате технико-технологического анализа нео-энеолитической керамики Поволжья и сопредельных регионов, а также многолетних экспериментальных работ выделены три вида ИПС, использовавшиеся в качестве сырья для изготовления бытовой посуды этого времени: uльl, илиcтые глины, глины. Подробная характеристика этих 
видов сырья и аргументация их выделения неоднократно опубликованы $[3 ; 11 ; 12]$. Технико-технологический анализ керамики стоянки ракушечный Яр позволил выявить два вида ИПС: илы и илистые глины. Причем для ранненеолитического гончарства было характерно использование только илов, илистые глины отмечены для энеолитической керамики стоянки (табл. 1). Качественный состав илов и илистых глин близок, что, по-видимому, отражает сходство процессов их осадконакопления и соответственно - близость расположения источников этих видов ИПС. Основное различие заключается в концентрации и размерности растительных остатков наземного и водного характера. Для определения концентрации была использована методика, основанная на подсчете числа включений растительности на площади $1 \mathrm{~cm}^{2}$ произвольно выбранного участка излома керамики и экспериментальных образцов с аналогичными органическими материалами. Введены условные степени концентрации: большая (10 и более включений или отпечатков на $1 \mathrm{~cm}^{2}$ ); средняя более 5 ; небольшая - 3-4; единичная - 1-2 на весь излом. К илам отнесено сырье, в котором зафиксированы большая и средняя степени концентрации, к илистым глинам - небольшая и единичная. В изученном илистом сырье присутствуют остатки (часто углефицированные) водной растительности в виде отпечатков нитевидных растений (водорослей), имеющих в разрезе плоско-овальную форму и размеры: длину до 1-2 см (и более) и диаметр 0,1-0,2 мм (рис. 1: 6), а также фрагментов листьев и извилистых стеблей различных растений длиной до 10 мм и более (рис. 1: 4-5), редко - зерен дикорастущих злаковых растений. Единично фиксируются компоненты водной фауны: мелкие фрагменты костей рыб (рис. 1: 10) и чешуи (рис. 1: 9) размером до 1-3 мм. В качестве естественных минеральных компонентов встречаются: 1) мелкие обломки раковины пресноводных моллюсков (рис. 1: 7-8); 2) песок (рис. 1: 3, 7); 3) различные железистые включения, реже представлен оолитовый бурый железняк; 4) оолитовые нерастворившиеся комочки чистой глины (высокопластичной и среднезапесоченной); 5) глинистые конкреции, насыщенные окислами железа; 6) мелкие аморфные карбонатные включения белого цвета.

На уровне подвидов ИПС выделены два: «тощие» и «жирные» (рис. 1: 1-3). Исследование этнографического гончарства свидетельствует о важности выделения этих подвидов пластичного сырья, т.к. гончары с древности обращали особое внимание на его чистоту и производили отбор того или другого в соответствии со своими традициями. В исследовательской практике наиболее распространенным способом оценки естественной песчаной примеси является разделение глин на сильно-, средне-, слабо- и незапесоченные, которое производится по подсчетам зерен песка на $1 \mathrm{~cm}^{2}$. В работе с неолитической керамикой мы используем наиболее общий подход: к «тощим» подвидам ИПС отнесены сильно- и среднезапесоченные, к «жирным» - слабо- и незапесоченные (в которых под бинокулярным микроскопом песчинки фиксируются в виде блеска, а не структурных отдельностей). Необходимо отметить, что для тощих подвидов ИПС неолитической керамики стоянки Ракушечный Яр характерно содержание преимущественно пылевидного песка и кварцевого ока- танного и полуокатанного песка с размером частиц 0,1-0,3 мм, редко 0,5-1 мм.

Bapианты ИПС определяются по наличию или отсутствию в сырье естественных обломков раковины пресноводных моллюсков. Данный признак показал свою важность в изучении неолитической керамики Поволжья. Нами была выявлена консервативность отбора ИПС с раковиной и формирование традиции добавления в ФМ предварительно подготовленной, дробленой раковины в качестве искусственной примеси в нео-энеолитическом гончарстве населения Поволжья, что свидетельствуют об очень большой культурной значимости данного технологического приема. Микроскопическое исследование неолитической керамики стоянки Ракушечный Яр показало практически полное отсутствие обломков раковины в илистом сырье. В небольшой части образцов, происходящих из слоев 23-18, наблюдалось присутствие мелких, незаметных глазу, единичных включений раковины размером менее 1 мм. Только начиная со слоя 17 стали встречаться фрагменты сосудов с визуально фиксируемыми обломками раковины размером до 3 мм.

Выделение районов и мест отбора ИПС, а следовательно, определение конкретных источников пластичного сырья в пределах острова Поречный, на котором находится стоянка Ракушечный Яр, не входило в задачи данной статьи. Однако на основании качественного состава илов и специфики минеральных компонентов можно предполагать определенную многочисленность мест отбора ИПС. Данный вывод подтверждают и результаты петрографического анализа керамики Ракушечный Яр, произведенного М.А. Кульковой [13].

На ступени обработки ИПС выявляются признаки состояния сырья (сухого или влажного), в котором оно находилось непосредственно перед составлением формовочной массы, а также определение возможных способов подготовки сырья: высушивания, дробления, просеивания и т.д. Современный методический уровень позволяет фиксировать состояние сырья, дробленного в сухом виде (по нерастворившимся комочкам глины, линзам разной цветности и др.). В случае отсутствия таких признаков предполагается использование ИПС во влажном состоянии. В неолитической керамике стоянки Ракушечный Яр присутствуют нерастворившиеся комочки чистой глины, как правило, уплотненные, имеющие оолитовую форму и отличающиеся от основного глинистого субстрата по цвету и степени запесоченности. По данным изучения современных илов и илистых глин присутствие такого естественного компонента весьма характерный признак этих видов ИПС. В целом, можно предполагать, что илистое сырье использовалось населением стоянки Ракушечный Яр в естественно увлажненном состоянии.

На ступени составления формовочной массы (ФМ) определяются особенности искусственных примесей и рецепты формовочных масс. Формовочная масса может быть подготовлена из какого-либо вида ИПС без искусственных примесей, а также из смеси ИПС и специально введенных органических и минеральных добавок. Микроскопическое изучение неолитической керамики стоянки Ракушечный Яр выявило только один вид искусственной добавки - 
Васильева И.Н.

Гончарная технология ранненеолитического населения Подонья

07.00.00 - исторические науки и археология

органические растворы (ОР), предположительно, клеящие природные жидкие вещества растительного или животного происхождения. После сушки и термической обработки они оставили в черепке керамики щелевидные плоскостные и аморфные объемные полости размером в среднем от 1 мм до $1 \mathrm{~cm}$. На поверхности растительности и на стенках пустот фиксируется налет вещества определенной плотности и цвета: молочно-белый «паутинообразный», маслянистый коричневато-черный, рыхлый рыжеватый, блестящие прозрачные пленки (рис. 1: 11-12). Пустоты рассредоточены по всей толще черепка и не связаны с проникновением нагара в поверхностные поры черепка. Органические растворы, по-видимому, бы- ли способны придавать керамическим изделиям полезные свойства: вязкость, влагонепроницаемость, прочность $[2 ; 11]$. В некоторой части изученных образцов керамики не выявлены признаки присутствия ОР, и сделано предположение об использовании ИПС без искусственных добавок. Общие данные по приемам составления ФМ керамики стоянки Ракушечный Яр представлены в табл. 2. В нее включена информация об искусственных примесях энеолитической керамики: дробленой раковине, песке, шамоте и пухе птиц. Данная таблица свидетельствует о том, что традиции введения в ФМ искусственных органических и минеральных добавок появляются у населения стоянки только в эпоху энеолита (табл. 2).

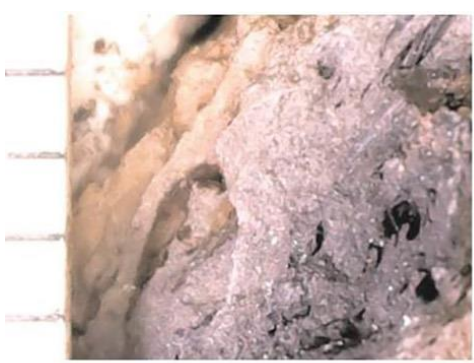

1

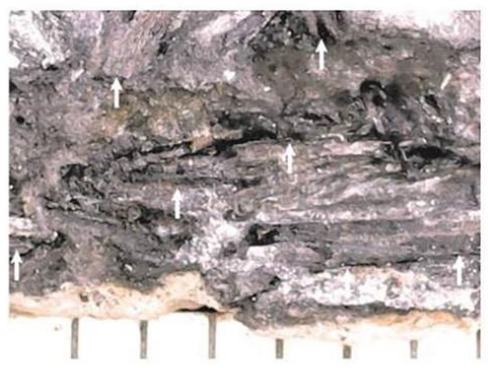

4

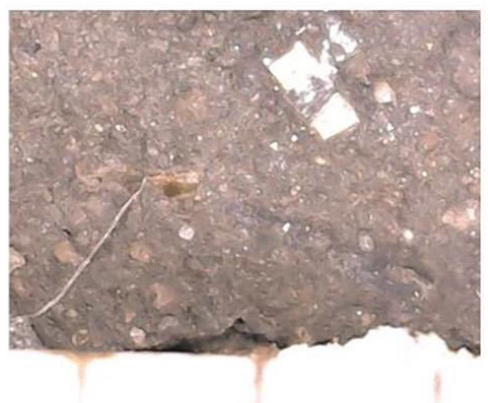

7

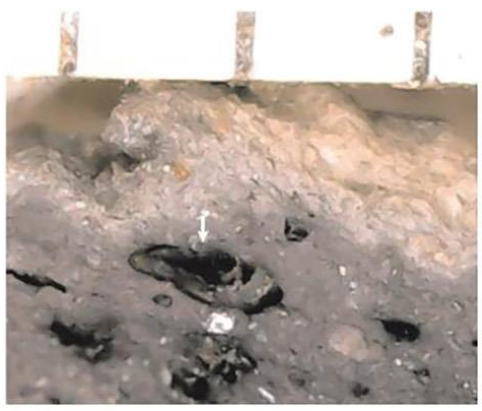

10

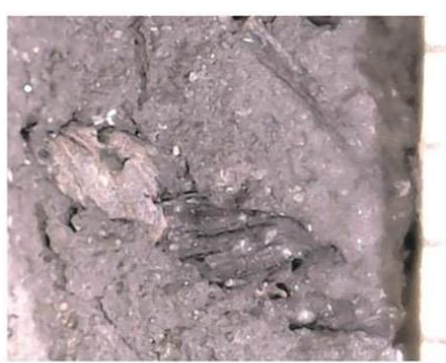

2

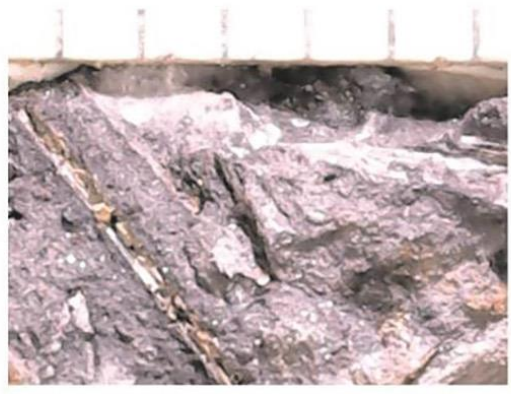

5

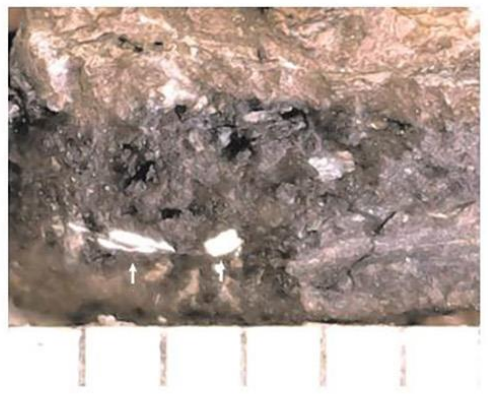

8

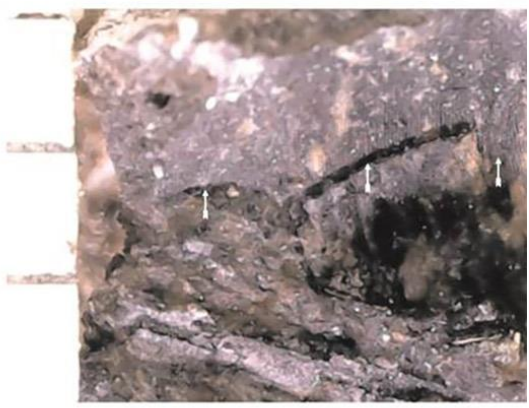

9

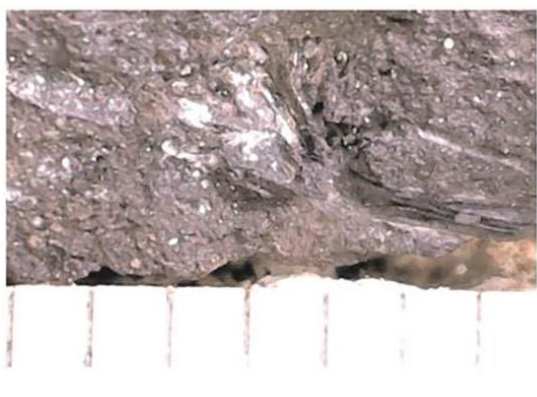

11

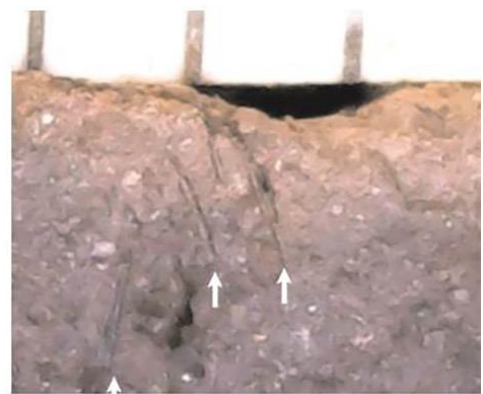

6

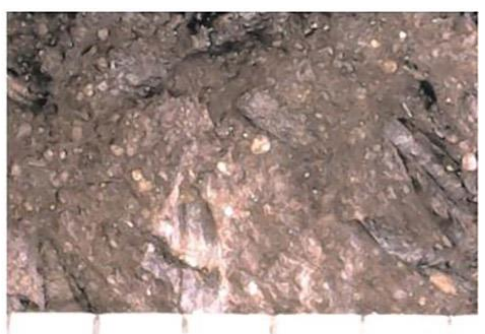

3

Рисунок 1 - Микрофотосъемка неолитической керамики стоянки Ракушечный Яр: исходное пластичное сырье и формовочные массы: 1-2- «жирные» илы; 3- «тощий» ил; 4-6- отпечатки растительности в ИПС; 7-8- включения естественной раковины в илах;

9- фрагмент чешуи рыбы; 10- фрагмент кости рыбы; 11-12- органический раствор 
Таблица 1 - Результаты изучения исходного пластичного сырья (ИПС) керамики стоянки Ракушечный Яр и I Раздорской стоянки (Нижнее Подонье)

\begin{tabular}{|c|c|c|c|c|c|c|c|c|c|c|c|}
\hline \multirow{4}{*}{ Стоянки, слои } & \multicolumn{10}{|c|}{ Виды ИПС } & \multirow{4}{*}{ Итого: } \\
\hline & \multicolumn{5}{|c|}{ Илы } & \multicolumn{5}{|c|}{ Илистые глины } & \\
\hline & \multicolumn{2}{|c|}{ тощие } & \multicolumn{2}{|c|}{ жирные } & \multirow{2}{*}{ Всего: } & \multicolumn{2}{|c|}{ тощие } & \multicolumn{2}{|c|}{ жирные } & \multirow{2}{*}{ Всего: } & \\
\hline & рак. & $\sigma / p$ & рак. & $\sigma / p$ & & рак. & $6 / p$ & рак. & $\sigma / p$ & & \\
\hline \multicolumn{12}{|c|}{ I Раздорская стоянка } \\
\hline Слой 1 (нижний) & 1 & 2 & 1 & - & 4 & - & - & - & - & - & 4 \\
\hline \multicolumn{12}{|c|}{ Стоянка Ракушечный Яр } \\
\hline 2 & - & - & 3 & - & 3 & 1 & 1 & 15 & 1 & 18 & 21 \\
\hline 3 & 1 & 1 & 4 & 4 & $\mathbf{1 0}$ & - & - & 15 & - & 15 & 25 \\
\hline 4 & - & 7 & 4 & 9 & 20 & - & - & 2 & - & 2 & 22 \\
\hline $5-5 a$ & 2 & 7 & 2 & 4 & 15 & - & - & - & - & - & 15 \\
\hline 7 & - & 1 & 2 & 4 & 7 & - & - & - & - & - & 7 \\
\hline 8 & 3 & 9 & 4 & 9 & 25 & - & - & - & - & - & 25 \\
\hline 9 & - & 2 & - & 4 & 6 & - & - & - & - & - & 6 \\
\hline 11 & - & 10 & 3 & 9 & 22 & - & - & - & - & - & 22 \\
\hline 12 & - & 7 & 3 & 7 & 17 & - & - & - & - & - & 17 \\
\hline 13 & - & 9 & - & 9 & 18 & - & - & - & - & - & 18 \\
\hline 14 & 1 & 8 & 2 & 18 & 29 & - & - & - & - & - & 29 \\
\hline 15 & - & 9 & - & 4 & 13 & - & - & - & - & - & 13 \\
\hline $16-17$ & - & 3 & 2 & 1 & 6 & - & - & - & - & - & 6 \\
\hline 18 & - & - & - & 6 & 6 & - & - & - & - & - & 6 \\
\hline 19 & - & 3 & - & 4 & 7 & - & - & - & - & - & 7 \\
\hline 20 & - & 6 & 1 & 17 & 24 & - & - & - & - & - & 24 \\
\hline 21 & - & 9 & 2 & 2 & 13 & - & - & - & - & - & 13 \\
\hline 23 & 1 & 9 & 2 & 6 & 18 & - & - & - & - & - & 18 \\
\hline \multirow[t]{3}{*}{$\begin{array}{l}\text { ИТОГО } \\
\text { по ст-ке Рак. Яр: }\end{array}$} & 8 & 100 & 34 & 117 & 259 & 1 & 1 & 32 & 1 & 35 & 294 \\
\hline & \multicolumn{2}{|c|}{$108 / 42 \%$} & \multicolumn{2}{|c|}{$151 / 58 \%$} & $100 \%$ & \multicolumn{2}{|c|}{$2 / 6 \%$} & \multicolumn{2}{|c|}{$33 / 94 \%$} & $100 \%$ & \\
\hline & \multicolumn{4}{|c|}{$\mathbf{2 5 9 / 8 8 \%}$} & & \multicolumn{4}{|c|}{$25 / 12 \%$} & & $100 \%$ \\
\hline ВСЕГО: & & & & & 263 & & & & & 35 & 298 \\
\hline
\end{tabular}

Примечание. ИПС - исходное пластичное сырье; рак. - ИПС с естественной раковиной; б/p - ИПС без естественной раковины. Ед. изучения - образец (отдельный сосуд).

Таблица 2 - Результаты изучения формовочных масс (ФМ) керамики стоянки Ракушечный Яр и I Раздорской стоянки (Нижнее Подонье)

\begin{tabular}{|c|c|c|c|c|c|c|c|c|}
\hline \multirow{2}{*}{ Слои } & \multicolumn{7}{|c|}{ Формовочные массы } & \multirow{2}{*}{ Итого: } \\
\hline & б/пр & OP & ДР+OP & ДР+ПП+ОР & ДР+П+ОР & $\Pi+Ш$ & $\mathrm{OP}+\amalg$ & \\
\hline \multicolumn{9}{|c|}{ I Раздорская стоянка } \\
\hline Слой 1 (нижний) & - & 4 & - & - & - & - & - & 4 \\
\hline \multicolumn{9}{|c|}{ Стоянка Ракушечный Яр } \\
\hline 2 & - & 3 & 10 & - & 6 & 1 & 1 & 21 \\
\hline 3 & - & 7 & 13 & 5 & - & - & - & 25 \\
\hline 4 & 3 & 16 & 3 & - & - & - & - & 22 \\
\hline $5-5 a$ & 5 & 7 & 3 & - & - & - & - & 15 \\
\hline 7 & 7 & - & - & - & - & - & - & 7 \\
\hline 8 & 2 & 23 & - & - & - & - & - & 25 \\
\hline 9 & 1 & 5 & - & - & - & - & - & 6 \\
\hline 11 & 9 & 13 & - & - & - & - & - & 22 \\
\hline 12 & 4 & 13 & - & - & - & - & - & 17 \\
\hline 13 & 1 & 17 & - & - & - & - & - & 18 \\
\hline 14 & 8 & 21 & - & - & - & - & - & 29 \\
\hline 15 & - & 13 & - & - & - & - & - & 13 \\
\hline $16-17$ & 4 & 2 & - & - & - & - & - & 6 \\
\hline 18 & 6 & - & - & - & - & - & - & 6 \\
\hline 19 & 5 & 2 & - & - & - & - & - & 7 \\
\hline 20 & 4 & 20 & - & - & - & - & - & 24 \\
\hline 21 & 3 & 10 & - & - & - & - & - & 13 \\
\hline 23 & 1 & 17 & - & - & - & - & - & 18 \\
\hline ВСЕГО по ст-ке Рак. Яр: & 63 & 189 & 29 & 5 & 6 & 1 & 1 & 294 \\
\hline ВСЕГО: & 63 & 193 & 29 & 5 & 6 & 1 & 1 & 298 \\
\hline
\end{tabular}

Примечание. ФМ - формовочные массы; б/np. - без примесей; OP - органический раствор; ДР - дробленая раковина; ПП - пух птиц; П - песок; Ш - шамот. Ед. изучения - образец (отдельный сосуд). 
Созидательная стадия. К данной стадии гончарной технологии относятся приемы конструирования сосудов (начинов, полого тела), способов придания им окончательной формы и обработки поверхностей. Степень сохранности изученных образцов позволяет охарактеризовать наиболее общие приемы изготовления сосудов. Можно уверенно сделать заключение о широком использовании лоскутного налепа. Оно основано на совокупности признаков лоскутного налепа, которая была выявлена экспериментальным методом: 1) многослойность изломов дна и стенок сосуда, обусловленная многочисленностью отдельных строительных элементов; 2) системность в наложении элементов, фиксируемая в продольных (вертикальных) изломах сосудов по однонаправленности спаев при спиралевидном лоскутном налепе и ее отсутствие - при комковатом бессистемном налепе; 3) особенности размеров строительных элементов в продольном и поперечном сечениях сосудов; 4) характер течения формовочной массы; 5) наличие признаков использования форм-моделей в виде статических следов на поверхностях сосудов (складок, морщинистости, отпечатков материала прокладок и самих форм-моделей) [14]. Распадение сосудов по кольцевой траектории может быть результатом применения спирально-зонального лоскутного налепа или конструирования сосуда по частям [15]. Применение способов лоскутного налепливания прослежено по керамике из всех культурных слоев стоянки Ракушечный Яр, начиная с нижнего 23 слоя. Можно выделить два основных приема: 1) лоскутный комковатый, в основном, с бессистемным наложением строительных элементов (расплющенных комочков ФМ размером не более $2 \times 2$ см) и размазыванием их по твердой модели; 2) налеп, производившийся, в основном, по круговой траектории из лоскутов (коротких жгутов, отрываемых от более длинного жгута). Примерные размеры этих строительных элементов: диаметр 1-1,5 см, длина 3-6 см. Данный прием мог быть связан как с применением форм-моделей, так и со скульптурной лепкой на плоскости. Изучение донных и придонных частей плоскодонных сосудов выявило использование донной и донноемкостной программ конструирования начинов. Характерной чертой технологических приемов на этой ступени технологии являлось наличие двухслойных днищ, которые могли появиться в нескольких случаях: 1) конструирование полого тела начиналось от центра уже изготовленного донного или донноемкостного начина и 2) за счет специального укрепления донной части сосуда дополнительными порциями строительных элементов. Иногда прием укрепления фиксировался только в месте перехода днища в стенки сосуда. Появление в керамическом комплексе стоянки Ракушечный Яр конусовидных днищ сосудов относится к слоям 13-11 [13, с. 41]. Их изучение выявило использование донно-емкостной программы начинов и лоскутного комковатого налепа с применением форм-моделей. По керамике из слоев 12-11 зафиксирован также прием специального уплощения изначально конусовидных днищ: в таких случаях днища сосудов приобретали некоторую вогнутость и округлодонность.
В качестве приемов формообразования предполагается применение форм-моделей и выбивание. Признаки применения форм-моделей (форм-емкостей и форм-основ) проявились в наличии складок, морщинистости, в основном, на внутренней поверхности сосудов. В качестве мягкого материала для прокладок можно предполагать очищенные шкуры. Немногочисленные факты, свидетельствующие об этом, выявлены по керамике из всех неолитических слоев. Признаки приема выбивания стенок сосудов как способа придания окончательной формы фиксируется по керамике 11 слоя.

На ступени обработки поверхностей сосудов выявлены механические приемы обработки поверхности сосуда: заглаживание, уплотнение (способ, аналогичный лощению, но без характерного блеска), реже лощение с матовым блеском. С самого нижнего 23 слоя прослеживается прием заглаживания твердым орудием, оставившим параллельные бороздки, похожим на гребенчатый штамп. Заглаживание производилось в горизонтальном и диагональном направлении. Обработке таким орудием подвергалась преимущественно внутренняя поверхность сосудов, но иногда и внешняя, только не полностью, а фрагментарно. В качестве орудий заглаживания применялись также гальки, щепа, кожа и др. Прием уплотнения-лощения использовался, в основном, для обработки внешней поверхности сосудов. Оно осуществлялось, по-видимому, отполированной галькой по сухой и подсушенной поверхности. В слое 18 обнаружены фрагменты сосудов, первоначально заглаженных твердым предметом типа гребенчатого штампа, а затем поверх этого заглаживания было произведено уплотнение-лощение.

Закрепительная стадия. Придание прочности и водонепроницаемости сосуду изучалось по следам влияния различных температур на первоначальную сохранность минеральных и органических компонентов, входивших в состав ФМ, а также по следам изменения первоначальной окрашенности поверхности и изломов посуды под действием разных температур и окружающей среды, что приводило к образованию различных цветовых прослоев излома черепка. Основным приемом придания прочности керамике был обжиг. Большинство изученных образцов имеют значительную механическую прочность. Зафиксированы следующие виды излома черепка: однотонный серый; трехслойный (с осветленными поверхностными прослоями и темно-серой сердцевиной); двухслойный (со светло-коричневым прослоем у внешней или внутренней поверхности и темносерой остальной частью черепка). Обращает на себя внимание большое количество обломков сосудов, поверхность которых яркого, светло-коричневого до оранжевого или желтого цвета. Толщина таких прослоев изнутри и снаружи составляет 1-3 мм. Сердцевина черепка черного цвета достигает 9-10 мм. Прослежена углефикация растительных остатков внутри этого слоя. Полученные данные свидетельствуют о костровом обжиге керамики с длительным периодом обжига при низких температурах в восстановительной атмосфере и довольно продолжительной выдержкой при температурах каления (650-700). На- 
Васильева И.Н.

ряду с «горячими» существовали и «холодные» способы в форме введения органических растворов. В целом, можно предполагать распространение смешанных способов придания прочности с помощью холодных и горячих (термических) воздействий на гончарные изделия и использование приемов неполной выдержки изделий при температурах каления глины, в результате чего они приобретали 2-3слойную окраску в изломе. Эти факты позволяют считать навыки труда гончаров стоянки Ракушечный Яр на закрепительной стадии частично сформированными [2, с. 85-89, 105].

Подводя итоги изучения неолитического гончарства населения стоянки Ракушечный Яр, следует охарактеризовать структуру гончарной технологии. Часть производств бытовой керамики без орнамента имело простейшую структуру (10 обязательных ступеней). Обращает на себя внимание, что традиции изготовления такой посуды были очень устойчивы: крупные плоскодонные неорнаментированные сосуды, изготовленные из ила с помощью простейшей структуры технологии, встречаются во всех неолитических слоях стоянки. Кроме того, они представлены в довольно большом количестве и в верхних слоях, вплоть до слоя 3. Другая часть производств имела простую структуру (10 обязательных и одна дополнительная ступень - орнаментирование). Оба вида производств относятся к протогончарныл, в которых илы выполняли функцию пластичного моносырья (без учета присутствия органических растворов) [2, с. 79]. Вся керамика стоянки сделана без использования гончарного круга и специализированных обжиговых устройств, что дает основание предполагать ее изготовление в рамках домашнего производства для нужд каждого отдельного домохозяйства. Совокупность наиболее массовых технологических традиций, характерных для гончарства неолитического населения стоянки, включает следующие:

- на подготовительной стадии - 1) распространение взглядов на илы как пластическое моносырье для изготовления бытовой посуды; 2) отбор тощих и жирных илов, с предпочтением последних (табл. 1); 3) массовые приемы отбора ИПС без визуально фиксируемой раковины; 4) влажное состояние ИПС непосредственно перед составлением ФМ; 5) добавление в ФМ только органических растворов;

- на созидательной стадии - 1) распространение приемов лоскутного налепливания; 2) использование в качестве строительных элементов комков и лоскутков (коротких жгутов); 3) бессистемное, кольцевое и спиралевидное наращивание лоскутков; 4) применение донной, донно-емкостной и смешанной программ конструирования начинов; 5) вероятное использование твердых форм-моделей с прокладками из мягких материалов; 6) простое заглаживание и сплошное уплотнение по сухой и подсушенной поверхности;

- на закрепительной стадии - 1) использование горячих и холодных приемов придания прочности сосудам; 2) соответствие представлений о термической обработке состоянию частичной сформированности [2, с. 89, 102].
Микроскопическому исследованию было подвергнуто 4 образца керамики - верхних частей разных сосудов из нижнего слоя I Раздорской стоянки (табл. 1-2). По мнению автора раскопок В.Я. Кияшко, этот слой относится к позднему неолиту. Изучение этих образцов выявило существенную близость технологических традиций с ракушечноярскими. Все они изготовлены из илов. Можно предполагать, что в период позднего неолита недалеко от стоянки Ракушечный Яр продолжало бытовать население с близкими культурными традициями в гончарстве. Возможно, дальнейшее археологическое изучение Нижнего Подонья приведет к открытию новых памятников и расширит границы данного очага древнейшего гончарства.

\section{Среднее и Верхнее Подонье}

До недавнего времени ранний неолит Верхнего и Среднего Подонья ассоциировался со среднедонской культурой, однако исследования Р.В. Смольянинова и А.В. Суркова дали основания рассматривать начало неолита на данной территории в рамках карамышевской культуры [16; 17]. К ней отнесены более 20 стоянок, сосредоточенных в основном в бассейне p. Воронеж. Наиболее ранний керамический комплекс карамышевского типа характеризуется прямостенными и биконическими, преимущественно остродонными сосудами, большая часть которых не орнаментирована. Авторы выделяют 2 этапа в его развитии: 1) к раннему этапу отнесена керамика, лощеная слабоорнаментированная, часть посуды орнаментирована ямочно-жемчужным пояском под венчиком, а также накольчатым и прочерченным орнаментом; 2) на втором этапе получает распространение посуда с расчесами и запесоченным составом черепка, орнаментированная ямками, глубокими наколами, гребенчатым штампом [16, с. 162].

Микроскопическому изучению было подвергнуто 185 образцов (отдельных сосудов карамышевского типа) из культурных слоев 14 стоянок Среднего и Верхнего Подонья: III Университетская, Плаутино I, Плаутино II, Ивница, Ступино, Устье р. Излегощи, Савицкое I, Карамышево 5, Карамышево 9, Ярлуковская протока, Липецкое озеро, Доброе 1, Васильевский кордон 5, Васильевский кордон 7. Отбор керамики для технико-технологического анализа был произведен авторами раскопок Р.В. Смольяниновым и А.В. Сурковым.

Ниже представлена общая характеристика гончарной технологии ранненеолитического населения данных регионов в соответствии со стадиями гончарного производства.

Подготовительная стадия. По изученным материалам Верхнего и Среднего Подонья выявлено два вида ИПС: иль и илистые глины. Из илов сделано всего 4 сосуда из изученных (2\% от общего количества) (табл. 3). Основным видом ИПС являлись илистые глины: сырье, в котором единично, но встречаются мелкие, часто углефицированные, остатки растительных тканей (детрит менее 1 мм, реже - более крупные фрагменты пластин и стеблей растений) (рис. 2: 1-3), отпечатки нитевидных растений (водорослей) длиной до 1-2 см (рис. 2: 4), отдельные 
Васильева И.Н.

Гончарная технология ранненеолитического населения Подонья

07.00.00 - исторические науки и археология

включения чешуи и костей рыбы (рис. 2: 5-б). В некоторых образцах зафиксированы разрушенные обломки раковины (менее 1-2 мм).

Характеристика навыков отбора сырья включает определение запесоченности сырья, прямо влиявшей на его пластичность, и присутствия естественных частиц раковины. Нами были выделены «тощие» и «жирные» подвиды ИПС (табл. 3). К «жирным» илистым глинам отнесены слабозапесоченные (условно пластичные), содержащие кварцевый песок размером, в основном, менее 0,2 мм и единичные включения песка размером менее 0,5 мм; слабозапесоченные, содержащие пылевидный песок размером менее 0,1 мм; незапесоченные (условно высокопластичные) глины, с полным отсутствием видимого под микроскопом песка. «Тощие» илистые глины включают среднезапесоченные (условно среднепластичные), с пылевидным песком и немногочисленными зернами песка 0,2-0,5 мм; запесоченные, содержащие большое количество пылевидного песка и фракцию кварцевого песка с размером зерен 0,2-0,5 мм; запесоченные, без видимого пылевидного песка, но с большим содержанием зерен песка 0,2-1 мм. Обломки раковины пресноводных моллюсков как компонент ИПС представлены в черепке образцов единичным или небольшим количеством мелких (в основном до 1 мм, реже - до 3 мм) полуразрушенных пластинок раковины белого цвета, как правило, без перламутра.

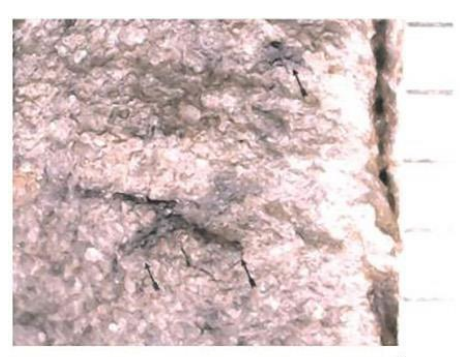

1

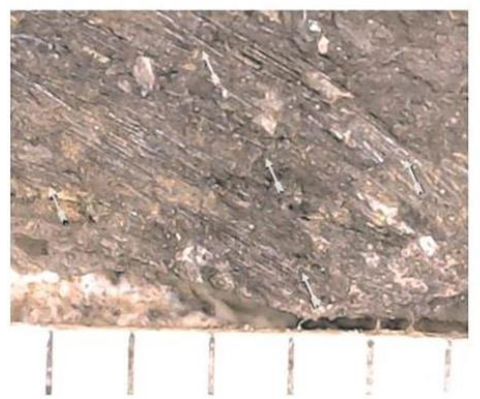

4

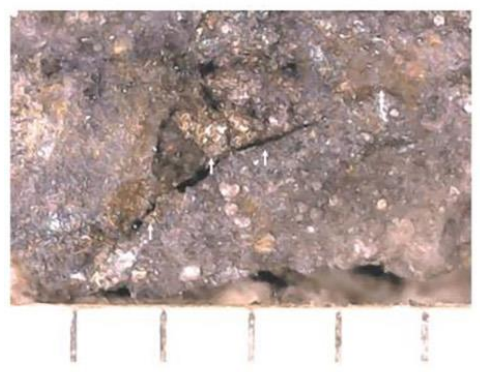

7

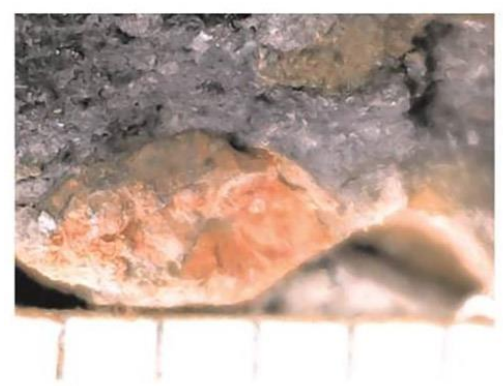

10

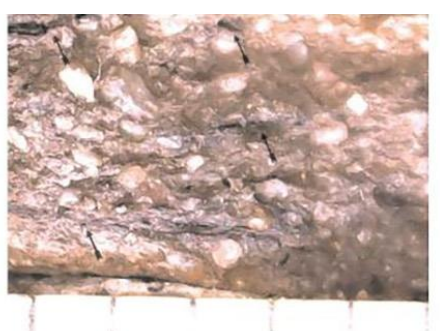

2

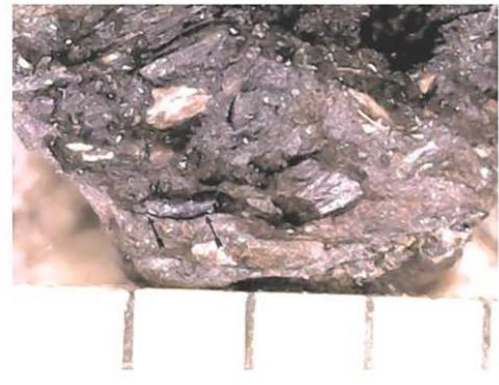

5

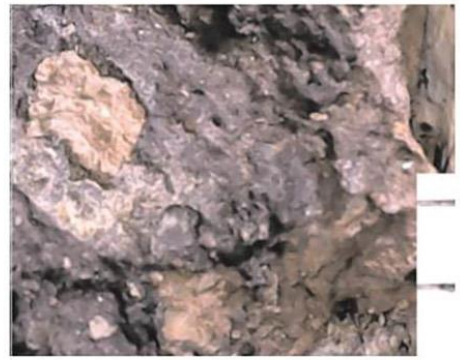

8

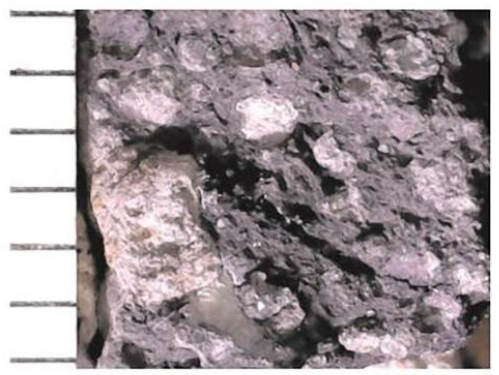

11

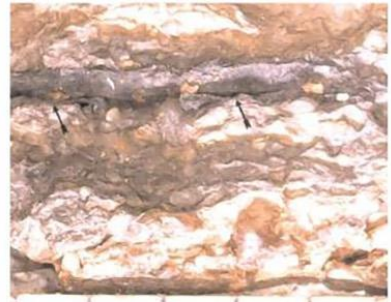

3

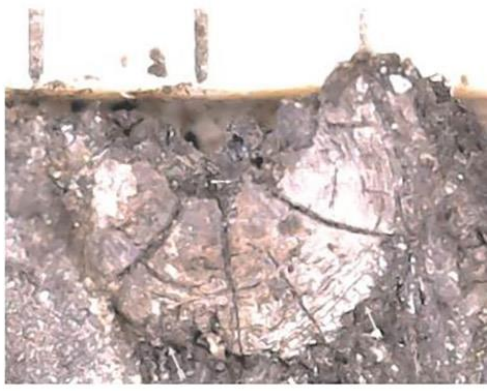

6

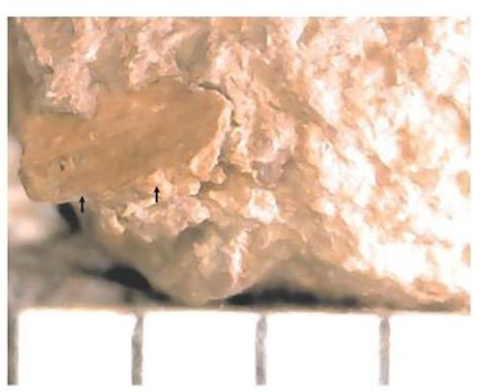

9

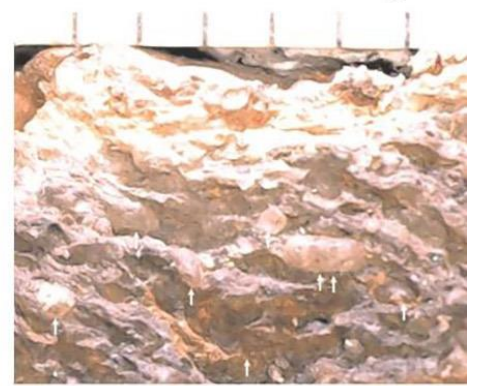

12

Рисунок 2 - Микрофотосъемка неолитической керамики карамышевского типа

из стоянок Среднего и Верхнего Подонья: исходное пластичное сырье и формовочные массы:

1-3- «тощие» илистые глины; 4- отпечатки водорослей в ИПС;

5- фрагмент кости рыбы; 6- фрагмент чешуи рыбы; 7- органический раствор;

8-9- шамот; 10-11- шамот-обожженная глина; 12- песок 
Васильева И.Н.

Таблица 3 - Результаты изучения исходного пластичного сырья (ИПС) керамики карамышевской культуры (Среднее и Верхнее Подонье)

\begin{tabular}{|c|c|c|c|c|c|c|c|c|c|c|c|}
\hline \multirow{4}{*}{ Стоянки: } & \multicolumn{10}{|c|}{ Виды ИПС } & \multirow{4}{*}{ Итого: } \\
\hline & \multicolumn{5}{|c|}{ Илы } & \multicolumn{5}{|c|}{ Илистые глины } & \\
\hline & \multicolumn{2}{|c|}{ тощие } & \multicolumn{2}{|c|}{ жирные } & \multirow{2}{*}{ Всего: } & \multicolumn{2}{|c|}{ тощие } & \multicolumn{2}{|c|}{ жирные } & \multirow{2}{*}{ Всего: } & \\
\hline & рак. & $\sigma / p$ & рак. & $\sigma / p$ & & рак. & $\sigma / p$ & рак. & $\sigma / p$ & & \\
\hline 1. III Университетская & - & - & - & - & 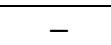 & 4 & 13 & 2 & - & 19 & 19 \\
\hline 2. Плаутино I & - & - & - & - & - & 3 & 18 & - & - & 21 & 21 \\
\hline 3. Плаутино II & - & - & - & - & - & - & 4 & - & - & 4 & 4 \\
\hline 4. Ивница & - & - & - & - & - & 10 & 11 & 2 & 11 & 34 & 24 \\
\hline $\begin{array}{l}\text { 5. Ступино } \\
\text { - нижний слой }\end{array}$ & - & - & - & - & - & 15 & 3 & - & - & 18 & 22 \\
\hline - верхний слой & - & - & - & - & - & - & 1 & - & 3 & 4 & \\
\hline 6. Устье р. Излегощи & - & - & - & - & - & - & 1 & - & - & 1 & 1 \\
\hline 7. Савицкое I & - & - & - & - & - & - & 1 & - & - & 1 & 1 \\
\hline 8. Карамышево 5 & - & - & - & - & - & 1 & - & 1 & - & 2 & 2 \\
\hline $\begin{array}{l}\text { 9. Карамышево } 9 \\
\text { - елшанский тип } \\
\text { - КТ с я/ж } \\
\text { - КТ с орн. } \\
\text { - } 2 \text { этап }\end{array}$ & $\begin{array}{l}- \\
- \\
- \\
- \\
\end{array}$ & $\begin{array}{l}- \\
- \\
- \\
-\end{array}$ & $\begin{array}{l}- \\
- \\
- \\
- \\
\end{array}$ & $\begin{array}{l}- \\
- \\
- \\
-\end{array}$ & $\begin{array}{l}- \\
- \\
- \\
-\end{array}$ & $\begin{array}{l}1 \\
8 \\
6 \\
-\end{array}$ & $\begin{array}{l}- \\
- \\
1 \\
3\end{array}$ & $\begin{array}{l}3 \\
4 \\
1 \\
-\end{array}$ & $\begin{array}{c}- \\
- \\
8 \\
21\end{array}$ & $\begin{array}{c}4 \\
12 \\
16 \\
24\end{array}$ & 56 \\
\hline 10. Ярлуковская протока & - & - & 2 & - & 2 & - & - & - & 2 & 4 & 4 \\
\hline 11. Липецкое озеро & - & - & - & - & - & 2 & 4 & - & - & 6 & 6 \\
\hline 12. Доброе 1 & - & - & - & 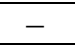 & - & - & 2 & - & - & 2 & 2 \\
\hline 13. Васильевский кордон 5 & 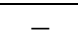 & - & 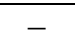 & 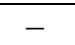 & 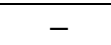 & - & 3 & 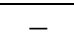 & 2 & 5 & 5 \\
\hline 14. Васильевский кордон 7 & - & 1 & - & 1 & 2 & - & 4 & - & 2 & 6 & 8 \\
\hline \multirow[t]{3}{*}{ ВСЕГО: } & - & 1 & 2 & 1 & \multirow{3}{*}{$\begin{array}{c}4 \\
100 \% \\
\end{array}$} & 50 & 69 & 13 & 49 & \multirow{3}{*}{$\begin{array}{c}181 \\
100 \% \\
\end{array}$} & 185 \\
\hline & & & $3 / 7$ & & & 119 & & & & & \\
\hline & \multicolumn{4}{|c|}{$4 / 2 \%$} & & \multicolumn{4}{|c|}{$181 / 98 \%$} & & $100 \%$ \\
\hline
\end{tabular}

Примечание. ИПС - исходное пластичное сырье; рак. - ИПС с естественной раковиной; б/p - ИПС без естественной раковины; $K T$ - карамышевский тип керамики; я/ж - с ямочно-жемчужным пояском под венчиком; орн. - орнаментированные. Ед. изучения - образец (отдельный сосуд).

В табл. 3 показано, что отбор «тощих» илистых глин был самой массовой традицией ранненеолитического населения (64\% от общего количества образцов из илистых глин). Преобладали приемы отбора ИПС без визуально фиксируемой раковины. Однако при сравнении данных по разным памятникам обнаруживаются определенные особенности. В среде населения, оставившего стоянку Ивница, навыки отбора ИПС с раковиной и без нее были распространены почти в равной степени, а на стоянке Ступино отбор тощих илистых глин с раковиной даже преобладал (табл. 3).

Детализация этой информации по памятникам, где были прослежены стратиграфические слои и выделены культурно-хронологические группы керамики, дала следующие результаты. На стоянке Ступино преимущественное преобладание керамики с раковиной характерно для нижнего, более раннего слоя. Bсе образцы керамики из верхнего слоя раковину в ИПС не содержали (табл. 3). Изучение материалов стоянки Карамышево 9 позволило выявить, что для изготовления посуды елшанского типа и посуды карамышевского типа без орнамента и с ямочножемчужным пояском использовалось только ИПС с раковиной. В производствах карамышевской керамики, орнаментированной накольчатым и другими видами орнамента, было распространено ИПС с раковиной и без нее. Для изготовления посуды, отнесенной ко 2 этапу, применялось только ИПС без раковины (табл. 3). Изучение керамики карамышевско- го типа позднего этапа, выявленной в материалах III Университетской стоянки, также показало преобладание сосудов из тощих илистых глин без раковины (68\% от всего количества) (табл. 3). Эти наблюдения указывают на изживание традиции отбора илистых глин с визуально фиксируемой раковиной в течение какого-то периода времени. На ступени подготовки ИПС было выявлено использование ИПС в естественно увлаженном состоянии.

Культурные традиции на ступени составления ФМ характеризуются данными о рецептах, которые включают ИПС и искусственные добавки. В качестве таковых были выявлены следующие: 1) органические растворы (ОР) (рис. 2: 7); 2) шамот (Ш) (рис. 3: 89) - порошкообразная минеральная примесь, полученная в результате дробления старых сосудов; 3) песок (П) (рис. 2: 12) - кварцевый, окатанный, с размером частиц 0,5-1,5 мм, реже до 2 мм; 4) шамотобожженная глина (Шо/г) (рис. 2: 10-11) - этот вид минеральных добавок был выделен нами по итогам изучения неолитической керамики Нижнего Прикамья и Сурско-Мокшанского междуречья [6; 7]. Данная примесь была предположительно идентифицирована нами как обожженная в виде комков в костре, а затем раздробленная, сильно ожелезненная глина. Отличие ее от шамота состоит в монолитности включений (отсутствии каких-либо примесей); сочетании остроугольных и округлых частиц при существенном преобладании последних, а также большом содержании глинистых частиц красно-коричневого 
Васильева И.Н.

Гончарная технология ранненеолитического населения Подонья

07.00.00 - исторические науки и археология

цвета. Наше предположение о характере данной минеральной примеси нашло подтверждение в исследовании М. Спатаро неолитической керамики стоянки Имерка VIII с помощью электронного микроскопа [18, с. 142-153]. Приемы составления ФМ изучались на подвидовом уровне: концентрации и размерности минеральных примесей, однако в данной статье указаны только компоненты рецептов. Следует отметить, что концентрация минеральных примесей не превышала следующих значений: единичной, 1:5 и $1: 4$, причем сосуды из ФМ с последней концентрацией немногочисленны. Данные факты свидетельствуют о том, что илистые глины использовались в качестве основного пластичного сырья. Состояние пред- ставлений о сырье можно охарактеризовать как частично сформированное.

В табл. 4 отражены результаты изучения ФМ керамики карамышевского типа (табл. 4). Зафиксированы 7 рецептов ФМ, два из которых относятся к смешанным (ИПС $+\mathrm{OP}+Ш+П ; \quad$ ИПС $+\mathrm{OP}+Ш о / \Gamma+П)$, существование которых отражает, по-видимому, процессы смешения между носителями разных гончарных традиций. Единично представлены сосуды, в ФМ которых не были обнаружены искусственные добавки (2 сосуда). Выделяются самые массовые традиции составления ФМ: 1) ИПС+ОР (42\%);

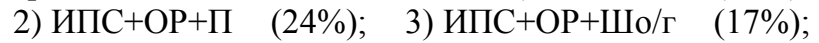
4) ИПС+ОР+Ш (10\%).

таблица 4 - Результаты изучения формовочных масс (ФМ) керамики карамышевской культуры (Среднее и Верхнее Подонье)

\begin{tabular}{|c|c|c|c|c|c|c|c|c|}
\hline \multirow{2}{*}{ Стоянки: } & \multicolumn{7}{|c|}{ Формовочные массы } & \multirow{2}{*}{$\begin{array}{c}\text { Ито- } \\
\text { го: }\end{array}$} \\
\hline & б/пр & OP & $\mathrm{OP}+\Pi$ & $\mathrm{OP}+Ш$ & OP+Ш+П & ОР+Шо/г & $\mathrm{OP}+\Pi+Ш о / \Gamma$ & \\
\hline 1. III Университетская & - & 6 & 6 & - & 2 & 5 & - & 19 \\
\hline 2. Плаутино I & 2 & 19 & - & - & - & - & - & 21 \\
\hline 3. Плаутино II & - & 3 & - & - & - & 1 & - & 4 \\
\hline 4. Ивница & - & 15 & 6 & 5 & 8 & - & - & 34 \\
\hline $\begin{array}{l}\text { 5. Ступино } \\
\text { - нижний слой } \\
\text { - верхний слой }\end{array}$ & - & $\begin{array}{c}17 \\
-\end{array}$ & $\begin{array}{l}1 \\
4\end{array}$ & - & - & - & - & $\begin{array}{c}18 \\
4\end{array}$ \\
\hline 6. Устье р. Излегощи & - & 1 & - & - & - & - & - & 1 \\
\hline 7. Савицкое I & - & - & 1 & - & - & - & - & 1 \\
\hline 8. Карамышево 5 & - & 1 & - & 1 & - & - & - & 2 \\
\hline $\begin{array}{l}\text { 9. Карамышево } 9 \\
\text { - елшанский тип } \\
\text { - КТ с я/ж } \\
\text { - КТ с орн. } \\
\text { - } 2 \text { этап }\end{array}$ & $\begin{array}{l}- \\
- \\
- \\
-\end{array}$ & $\begin{array}{l}- \\
9 \\
3 \\
-\end{array}$ & $\begin{array}{c}- \\
- \\
7 \\
19\end{array}$ & $\begin{array}{l}- \\
- \\
1 \\
-\end{array}$ & $\begin{array}{l}- \\
- \\
- \\
-\end{array}$ & $\begin{array}{l}4 \\
3 \\
5 \\
4\end{array}$ & $\begin{array}{l}- \\
- \\
- \\
1\end{array}$ & $\begin{array}{c}4 \\
12 \\
16 \\
24\end{array}$ \\
\hline 10. Ярлуковская протока & - & 2 & - & 2 & - & - & - & 4 \\
\hline 11. Липецкое озеро & - & 1 & 1 & - & - & 4 & - & 6 \\
\hline 12. Доброе 1 & - & - & - & 2 & - & - & - & 2 \\
\hline 13. Васильевский кордон 5 & - & - & - & 3 & - & 2 & - & 5 \\
\hline 14. Васильевский кордон 7 & - & - & - & 5 & - & 3 & - & 8 \\
\hline ВСЕГО: & 2 & 77 & 35 & 19 & 10 & 31 & 1 & 185 \\
\hline
\end{tabular}

Примечание. ФМ - формовочные массы; б/np. - без примесей; $O P$ - органический раствор; $П-$ песок; $U$ - шамот; Шо/2 - шамот-обожженная глина; $K T$ - карамышевский тип керамики; я/ж - с ямочно-жемчужным пояском под венчиком; орн. - орнаментированные. Ед. изучения - образец (отдельный сосуд).

Анализ материалов стоянок Ступино и Карамышево 9 позволил выяснить некоторые тенденции распространения разных традиций составления ФМ. В нижнем слое Ступино очевидно преобладание керамики, изготовленной из ИПС с добавкой ОР (94\% от общего количества), и только один сосуд был сделан из ФМ с искусственно введенным песком. В верхнем слое все изученные сосуды содержат примесь песка (табл. 4). Изучение керамики стоянки Карамышево 9 дало следующие результаты (табл. 4). Во-первых, все изученные сосуды елшанского типа изготовлены из ФМ: ИПС+ОР+Шо/г. Во-вторых, сосуды карамышевского типа без орнамента и с ямочно-жемчужным пояском сделаны преимущественно из ФМ с одним только ОР (75\% от общего количества этого типа), четверть таких сосудов $(25 \%)-$ из ФМ: ИПС+ОР+Шо/г. В-третьих, рецепты ФМ сосудов карамышевского типа, орнаментированных различными видами орнамента, более разнообразны они включают все вышеназванные и еще: ИПС+ОР+Ш. В-четвертых, керамика, отнесенная ко 2 этапу, изготовлена из ФМ с примесью ОР + П $(79 \%$ от количества образцов данного этапа), с примесью
ОР+Шо/г (17\%) и по смешанному рецепту ОР+Шо/г+П (4\%). Эти данные свидетельствуют о том, что наиболее ранними традициями составления ФМ керамики карамышевского типа были две: 1) ИПС+ОР и 2) ИПС+ОР+Шо/г. Возможно, к ним относилась и «шамотная» традиция. Прием введения искусственного песка в ФМ появился позднее в рамках карамышевской культуры. Характер его появления пока не ясен. Данная традиция могла зародиться в ранненеолитическом карамышевском гончарстве в ходе эволюционного развития - аналогично зарождению и распространению традиции искусственного введения дробленой раковины в ФМ керамики орловской культуры степного Поволжья. В то же время, она могла появиться с новой группой неолитического населения из районов, материалы которых пока не изучены. Очевидно, что данный вопрос требует дальнейшей разработки.

Созидательная стадия. Данные о приемах конструирования сосудов (начинов, полого тела), способов придания им окончательной формы, а также приемов обработки их поверхностей не столь многочисленны. Можно предполагать, что конструирова- 
ние сосудов карамышевского типа производилось лоскутным налепом с использованием различных форм-моделей. Строительными элементами служили лоскуты длиной 2-3 см (небольшие фрагменты от длинного жгута толщиной 1-1,5 см). Признаки применения форм-моделей проявились в наличии складок, морщинистости, редко - статических отпечатков волос животных на внутренних и внешних поверхностях сосудов. Микроскопическое изучение линий спаев и систем наложения лоскутков в изломах сосудов, а также наличие статических отпечатков на внутренних и внешних поверхностях сосудов показало возможность применения как форм-емкостей, так и форм-основ. Зафиксированы приемы зонального спиралевидного лоскутного налепа или изготовления сосуда по частям. В качестве дополнительного приема формообразования использовалось выбивание, поэтому толщина стенок сосудов иногда достигает всего 4-5 мм. Можно отметить тенденцию укрупнения размеров и утолщения стенок сосудов данного типа на позднем этапе.

Основными способами обработки поверхностей сосудов были механические: заглаживание твердым предметом типа гребенчатого штампа и уплотнение (лощение по сухой и подсушенной основе, без характерного блеска). Уплотнение производилось, повидимому, с помощью отполированных твердых предметов (галька, кость). Можно выделить 4 наиболее распространенные схемы обработки поверхности сосудов; 1) внешняя поверхность - уплотнение, внутренняя - мягкий материал, статические отпечатки, шероховатость; 2) внешняя и внутренняя поверхности - уплотнение; 3) внешняя поверхность - уплотнение, внутренняя - заглаживание гребенчатым штампом; 4) внешняя и внутренняя поверхности - заглаживание гребенчатым штампом, поверх этого орудия - уплотнение, иногда практически уничтожающее следы предыдущего заглаживания. Изучение керамики из разных слоев стоянки Ступино показало, что сосуды из нижнего слоя были подвергнуты уплотнению (в соответствии с 1 и 2 схемами); все образцы из верхнего слоя имеют признаки заглаживания обеих поверхностей гребенчатым штампом (схема 4). Похожие результаты показал анализ керамики стоянки Карамышево 9: преобладающая часть посуды, отнесенной к раннему этапу, имеет следы уплотнения, и только небольшая часть заглажена гребенчатым штампом. И наоборот: практически вся керамика 2 этапа заглажена гребенчатым штампом, только единичные сосуды не имеют признаков заглаживания этим орудием. Следует отметить, что прием обработки поверхностей сосудов гребенчатым штампом, а поверх него - уплотнением носит смешанный характер и отражает изменения в навыках обработки поверхностей, связанные с процессами смешения разных в культурном отношении групп неолитического населения.

Закрепительная стадия. Придание прочности и устранение влагопроницаемости достигалось путем обжига. Характер излома черепка: трехслойный (с осветленными поверхностными прослоями и темносерой или черной сердцевиной); двухслойный (со светло-коричневым прослоем у внешней или внутренней поверхности и темно-серой остальной частью черепка); полностью серый или черный. Можно предполагать, что посуда подвергалась длительному обжигу, в основном, при низких температурах в восстановительной среде, с кратковременным пребыванием в условиях температур каления (выше $650^{\circ}$ ). Использовались реликтовые «холодные» способы в форме введения органических растворов. Распространение смешанных способов придания прочности с помощью холодных и горячих (термических) воздействий на сосуды и использование приемов неполной выдержки изделий при температурах каления глины указывает на то, что навыки труда гончаров карамышевской культуры на закрепительной стадии являлись частично сформированными [2, с. 85-89, 105].

Обобщая полученные данные по гончарной технологии населения карамышевской культуры, охарактеризуем структуру гончарной технологии. Часть производств бытовой керамики без орнамента имело простейшую структуру (10 обязательных ступеней). Другая часть производств имела простую структуру (10 обязательных и одна дополнительная ступень - орнаментирование). Первый вид производств относится к протогончарным, в которых илистые глины выполняли функцию пластичного моносырья (Ф4) (без учета присутствия органических растворов). Переход на илистые глины и составление ФМ из них с минеральными добавками примеси (шамотом, шамотом-обожженной глиной, песком) мы связываем с архегончарным уровнем развития гончарства. Керамика карамышевского типа изготовлена без использования гончарного круга и специализированных обжиговых устройств, в рамках домашнего производства для нужд каждого отдельного домохозяйства. Выделена следующая совокупность наиболее массовых технологических традиций:

- на подготовительной стадии - 1) распространение взглядов на илистые глины как пластическое сырье для изготовления бытовой посуды; 2) отбор тощих и жирных подвидов ИПС, с предпочтением тощих (табл. 3); 3) изживание приемов отбора ИПС с раковиной; 4) влажное состояние ИПС непосредственно перед составлением ФМ; 5) сокращение традиции добавки в ФМ только органических растворов (42\%, для сравнения: в Ракушечном Яре - практически $100 \%$ ) (табл. 2 и 4); 6) существование традиции введения минеральных примесей в ФМ (шамота, шамота-обожженной глины, песка);

- на созидательной стадии - 1) распространение приемов лоскутного налепливания; 2) использование в качестве строительных элементов мелких лоскутков; 3) в основном, спиралевидное наращивание лоскутков; 4) применение твердых форм-моделей с прокладками из мягких материалов; 6) обработка поверхности путем заглаживания твердым предметом типа гребенчатого штампа и сплошного уплотнения по сухой и подсушенной основе, реже - лощения;

- на закрепительной стадии - 1) использование горячих и холодных приемов придания прочности сосудам; 2) соответствие представлений о термической обработке состоянию частичной сформированности [2, с. 89, 102].

\section{Заключение}

Полученные по единой методике данные о гончарной технологии ранненеолитического населения 
Васильева И.Н.

Гончарная технология ранненеолитического населения Подонья

07.00.00 - исторические науки и археология

двух регионов Подонья дают основание для их сравнительного анализа, выяснения взаимосвязей и взаимовлияния. Итоги этого анализа в краткой форме подведены в табл. 5. Сравнительное изучение прово- дилось по наиболее важным показателям форм, орнамента и гончарной технологии. При этом учитывались массовые традиции, характерные для раннего периода существования культур.

Таблица 5 - Результаты сравнительного изучения данных по гончарной технологии ранненеолитического населения стоянки Ракушечный Яр (Нижнее Подонье) и карамышевской культуры (Среднее и Верхнее Подонье)

\begin{tabular}{|c|c|c|c|}
\hline № & Основные черты гончарного производства & $\begin{array}{l}\text { Нижнее Подонье } \\
\text { (ракушечноярская } \\
\text { культура) }\end{array}$ & $\begin{array}{l}\text { Верхнее и Среднее } \\
\text { Подонье (карамы- } \\
\text { шевская культура) }\end{array}$ \\
\hline 1 & Форма сосудов & плоскодонная & конусовидная \\
\hline 2 & $\begin{array}{l}\text { Орнамент: } \\
\text { - отсутствует } \\
\text { - ямочно-жемчужный поясок } \\
\text { - прочерченный } \\
\text { - накольчатый }\end{array}$ & $\begin{array}{l}+ \\
- \\
+ \\
+\end{array}$ & $\begin{array}{l}+ \\
+ \\
+ \\
+\end{array}$ \\
\hline 3 & ИПС & $\begin{array}{l}\text { Илы, жирные, } \\
\text { без раковины }\end{array}$ & $\begin{array}{c}\text { Илистые глины, } \\
\text { тощие, с раковиной }\end{array}$ \\
\hline 4 & $\begin{array}{l}\text { Компоненты ФМ: } \\
\text { - б/пр и ОР } \\
\text { - шамот } \\
\text { - шамот-обожженная глина } \\
\text { - песок }\end{array}$ & $\begin{array}{l}+(100 \%) \\
- \\
- \\
-\end{array}$ & $\begin{array}{l}+(42 \%) \\
+ \\
+ \\
+ \\
+\end{array}$ \\
\hline 5 & $\begin{array}{l}\text { Конструирование: } \\
\text { лоскутный налеп, применение форм-моделей }\end{array}$ & + & + \\
\hline 6 & $\begin{array}{l}\text { Обработка поверхности: } \\
\text { - уплотнение (лощение) } \\
\text { - заглаживание орудием типа гребенчатого щтампа }\end{array}$ & $\begin{array}{l}+ \\
+\end{array}$ & $\begin{array}{c}+ \\
+(\text { на позднем этапе })\end{array}$ \\
\hline 7 & $\begin{array}{l}\text { Придание прочности и влагонепроницаемости: } \\
\text { - сочетание горячих и холодных приемов } \\
\text { - обжиг с короткой выдержкой при температурах каления } \\
\text { - обжиг с более длительной выдержкой } \\
\text { при температурах каления }\end{array}$ & $\begin{array}{l}+ \\
+ \\
+\end{array}$ & $\begin{array}{l}+ \\
+ \\
-\end{array}$ \\
\hline 8 & $\begin{array}{l}\text { Уровни эволюционного развития гончарства: } \\
\text { - протогончарство } \\
\text { - переход к архегончарству }\end{array}$ & $\begin{array}{l}+ \\
-\end{array}$ & $\begin{array}{l}+ \\
+\end{array}$ \\
\hline
\end{tabular}

Сравнение форм и орнаментации сосудов выявило очевидные различия. Для керамического комплекса нижних слоев стоянки Ракушечный Яр были характерны плоскодонные, довольно массивные, неорнаментированные сосуды. Посуда карамышевского типа на раннем этапе - остродонная, с более тонкими стенками, без орнамента или с ямочножемчужным пояском под венчиком. Вероятно, традиции декорирования в технике накалывания и прочерчивания получили широкое распространение несколько позднее в обоих комплексах.

Сравнение технологических традиций следует начать с представлений об исходном пластичном сырье, т.к. они относятся к субстратным навыкам труда в гончарстве, не изменяющимся очень длительное время даже в условиях культурного смешения. При изучении поселенческого керамического материала представления о сырье приобретают особое значение, поскольку информация о других субстратных навыках (конструирования начинов, полого тела, формообразования) крайне малочисленна. Они позволяют рассматривать вопросы сложения гончарной технологии древнего населения, процессов культурного взаимодействия и т.д. Технико-технологический анализ керамики стоянки Ракушечный Яр выявил полное распространение взглядов населения на илы как сырье для изготовления бытовой посуды. При этом наибольшую массовость имели традиции отбора «жирных» илов, без визуально фиксируемых обломков раковины пресноводных моллюсков. Для карамышевского населения были характерны представления об илистых глинах как сырье. Наиболее массовыми были приемы отбора «тощих» илистых глин с раковиной. Таким образом, выявляется существенное различие гончарных традиций этих двух групп ранненеолитического населения Подонья. И оно имеет принципиальное значение, т.к. указывает на разные очаги происхождения гончарства. Важным отличием карамышевского гончарства является распространение традиций введения в массы минеральных примесей, что является отражением перехода к архегончарству, когда пластичное сырье становится не моносырьем, а только основным сырьем, к которому добавляются минеральные примеси. Таким образом, можно говорить и о разных уровнях эволюционного развития гончарства: если ракушечноярское относится полностью к протогончарному, то карамышевское показывает тенденцию перехода к архегончарному.

Некоторые различия существовали в приемах обжига. Значительная часть керамики стоянки Ракушечный Яр обнаруживает признаки более длительного нахождения в температурах каления, о чем свидетельствуют окрашенность поверхностей в яркие светло-коричневые (до оранжевого) цвета и мощность краевых окислительных прослоев черепка. Такой режим обжига возможен для сырья, не содержащего обломки раковины, которая быстро разрушается в условиях высоких температур при соприкосновении с кислородом. Такой режим мог сформиро- 
Васильева И.Н

ваться в гончарстве, основанном на илистом сырье без существенной примеси раковины. Но, в целом, представления гончаров обоих регионов о термической обработке соответствуют состоянию частичной сформированности, что, по-видимому, является отражением уровня эволюционного развития.

Особого внимания заслуживает вопрос о приемах конструирования. Мы фиксируем способ лоскутного налепливания для ранненеолитического гончарства обоих регионов. Следует напомнить, что выделение данного приема конструирования сосудов принадлежит А.А. Бобринскому. Основанием для этого послужили результаты микроскопического исследования археологической керамики, этнографические данные, а также сохранившиеся реликты в современной гончарной технологии. Он пришел к выводу, что по признаку системности принципов наращивания глины навыки работы могут быть выстроены в своеобразную цепочку, начальные звенья которой составляют приемы лоскутного налепливания глины, а конечные - приемы спирального наращивания глиняных жгутов [1, с. 158]. А.А. Бобринскому удалось установить, что в течение последних трех тысячелетий в восточноевропейском гончарстве развивались три массовых процесса эволюции и перерождения навыков конструирования. В I тыс. до н.э. и практически все I тысячелетие н.э. происходило перерождение лоскутного налепа; с конца I тыс. н.э. - кольцевого налепа; а после XV-XVI вв. - перерождение спирального способа конструирования [1, с. 167]. Завершение эволюции лоскутного налепа было отнесено им предположительно к началу II тыс. н.э. - времени почти полного его исчезновения как самостоятельного принципа конструирования. Большую роль в этом сыграли процессы смешения носителей навыков лоскутного налепа с группами населения, владевшего более совершенными приемами ее изготовления (спиральным и кольцевым налепами). При этом А.А. Бобринский подчеркивал, что за постепенными изменениями технологических приемов конструирования посуды не стояла радикальная смена самого населения. Просто в разные промежутки этого длительного периода возникали процессы смешения между носителями разных традиций изготовления керамики, которые постепенно и привели к полному перерождению лоскутного налепа [1, c. 168]. Наше исследование гончарной технологии показали полное распространение принципов лоскутного налепливания в эпоху неолита и энеолита на территории Поволжья и сопредельных регионов. Данный факт отражает определенный уровень эволюционного развития древнего гончарства, поэтому не может служить критерием при выяснении сходства или различия гончарных традиций разных групп неолитического населения. Хотя, если бы сохранность поселенческой посуды была полнее, возможно, можно было бы выявить какие-то характерные особенности.

Обращаясь к теме формирования и распространения гончарных традиций в Подонье, необходимо обратиться к материалам соседнего крупнейшего региона - Поволжья. В бассейне р. Волги нами было выделено два ранних очага гончарства: средневолжский (елшанский) и североприкаспийский [9; 19]. По этим материалам получены серии радиоуглеродных дат, совокупность которых укладывается в рамки первой половины VII тыс. кал. л. до н.э. (при наличии самых ранних абсолютных дат).
1. Средневолжский (елшанский) очаг характеризуется наличием остродонных, прямостенных и профилированных, сосудов небольших размеров, без орнамента, иногда с просверленными после обжига отверстиями. Отмечен процесс формирования приемов орнаментирования, связанных с технологией изготовления сосудов в формах-моделях: ямочножемчужного пояска. ИПС - тощие илистые глины, как правило, без включений визуально фиксируемой естественной раковины, хотя есть небольшая часть керамики из ИПС с раковиной. ФМ составлялись с добавкой ОР. Конструирование производилось лоскутным налепом в формах-моделях, с использованием кожаных прокладок (неочищенных шкур животных). В качестве строительных элементов применялись мелкие лоскутки, отрываемые от жгута. Поверхность сосудов подвергалась сплошному уплотнению. Излом черепка чаще всего трехслойный: поверхностные слои - осветленные, толщиной 0,11 мм, сердцевина черепка - черная, толщиной 46 мм. Можно предполагать костровой обжиг с длительным периодом при низких температурах в восстановительной среде (без доступа кислорода) и непродолжительной выдержкой при температурах каления $\left(650-700^{\circ}\right)$.

2. Североприкаспийский очаг представлен более крупными плоскодонными, прямостенными и профилированными, сосудами, орнаментированными в прочерченной технике, с разреженными наколами. Часть ранних сосудов не орнаментирована. В более позднее время наибольшее распространение получает накольчатая техника орнаментации. ИПС - тощие и жирные илы, с большим содержанием сгнившей растительности и обломков пресноводных раковин (иногда - мелких целых улиток). ФМ включали искусственную добавку ОР. Способы конструирования сосудов - лоскутный комковатый налеп, предполагавший размазывание комочков ФМ в виде «лепешек» по стенкам форм-моделей. Поверхность сосудов подвергалась сплошному уплотнению твердым гладким предметом. Излом черепка, как правило, с трехслойной цветовой структурой: поверхностные слои толщиной 0,1-1 мм - светло-коричневые, сердцевина толщиной 5-10 мм - черного цвета. Использовался костровой обжиг с длительным периодом при низких температурах в восстановительной среде и кратковременной выдержкой при температурах каления. Сохранность обломков раковины и углефикация остатков растительности в черепке указывает на применение режима, при котором сосуды долго находились в изоляции от открытого огня (использование прокладки из золы?).

Сравнительный анализ ранненеолитических гончарств Поволжья и Подонья показывает, что наибольшая близость гончарных традиций прослеживается между североприкаспийскими и ракушечноярскими, с одной стороны, и средневолжскими (елшанскими) и карамышевскими - с другой стороны.

Сходство ранних гончарств Северного Прикаспия и Нижнего Подонья, в рамках которых изготавливались плоскодонные сосуды из илов, может быть объяснено тем, что они относились к одному ареалу зарождения гончарства, история которого была связана с использованием илистого сырья. По материалам памятников данных регионов получены серии радиоуглеродных дат в рамках первой половины VII тыс. кал. л. до н.э. (при наличии самых ранних абсолютных дат для неолита Восточной Европы). Исходя 
из гипотезы А.А. Бобринского, можно предполагать самостоятельный характер зарождения в Волго-Донском междуречье гончарств, основанных на использовании илов в качестве сырья для изготовления бытовой посуды. Вместе с тем, выявились довольно существенные различия: 1) в орнаментальных традициях; 2) в традициях отбора ИПС (отсутствие естественной примеси раковины в ИПС ракушечноярской керамики и насыщенность ею ИПС североприкаспийской керамики); 3) в приемах обжига сосудов. Причины этих различий могут носить хронологический или культурный характер, что нуждается в дальнейшем тщательном изучении. Рассуждения А.А. Бобринского очень важны для понимания общих процессов развития гончарной технологии как культурного явления в истории древнего населения. Очевидно также, что эти процессы в разных культурно-исторических зонах имели определенную конкретику и специфику. К настоящему времени наиболее полно изучено неолитическое гончарство Нижнего Поволжья, основанное на использовании илов. Была выявлена основная тенденция развития представлений об ИПС в эпоху неолита в рамках культур с прочерченно-накольчатой керамикой: илы - илистые глины - глины. Причем у разных групп неолитического населения процесс изменения взглядов на характер пластического сырья растянулся на очень длительное время. Население орловской культуры стало использовать илистые глины и глины уже в ранний период среднего неолита (Варфоломеевка, слой 3), однако часть населения этой культуры сохраняло свои представления об илах как сырье и в более позднее время (Орловская стоянка). В Северном Прикаспии происходившие вокруг эволюционные изменения в гончарстве не затронули группу поздненеолитического населения, оставившего стоянку Тентексор I. По имеющимся данным появление илистых глин в Северном Прикаспии относится только к началу энеолита (прикаспийская культура). Переход к новому сырью (илистым глинам) сопровождался формированием традиции введения искусственной добавки - дробленой раковины. Показателен тот факт, что исследование неолитической керамики Северного и Северо-Западного Прикаспия (Каир-Шак, Тентек-сор, Джангар и др.), а также орловской АК (Орловка, Варфоломеевка) показало полное отсутствие «шамотной» традиции в данном регионе. Основным, искусственно введенным компонентом в ФМ были органические растворы, а позднее дробленая раковина. Тенденции развития и трансформации неолитического гончарства Подонья пока не ясны. Обращает на себя внимание факт определенной консервации навыков отбора илов, аналогично Северному Прикаспию, до эпохи энеолита (Ракушечный Яр), что сближает эти регионы. Предварительное изучение керамики черкасского типа и нижнедонской культуры также выявило традиции изготовления части керамики из илистого сырья. Возможно, дальнейшее изучение керамики этих типов поможет установить истоки этих традиций.

Отнесение карамышевского керамического комплекса к ранненеолитическим основано на том, что он является самым ранним на территории Среднего и Верхнего Подонья. Однако существующие абсолютные даты указывают на его более позднюю хронологическую позицию по сравнению с ракушечноярской культурой [16, с. 163]. Данные о карамышевской гончарной технологии показали ее существенные различия с более ранним ракушечноярским гончарством. Это свидетельствует о том, что происхождение гончарной технологии данной группы населения не было связано с нижнедонским очагом раннего гончарства. В то же время они позволяют установить определенную преемственность и близость гончарных традиций ранненеолитических групп Среднего и Верхнего Подонья с елшанскими традициями населения Среднего Поволжья [4]. Время формирования здесь ранненеолитической культуры относится к первой половине VII тыс. кал. л. до н.э. (при наличии самых ранних абсолютных дат). Предположительно, появление елшанской культуры в Волго-Уралье было связано с миграцией неолитического населения из Восточного Прикаспия и Среднеазиатского междуречья и смешением его с местными мезолитическими коллективами. Для елшанского гончарства было характерно использование илистых глин (чаще всего запесоченных), а также составление ФМ с ОР, реже с шамотом. Позднее Волго-Уралье стало зоной контактов и смешения неолитических коллективов с прочерченно-накольчатой керамикой, изготовленной из илов, и елшанскими группами древнего населения, которые делали посуду из илистых глин с ОР и реже с добавкой шамота. Процесс взаимодействия и смешения между ними выявлен по материалам ряда стоянок Самарской и Оренбургской областей. Его результатом стало сложение средневолжской культуры. Часть елшанского населения не вступало в процессы смешения с мигрантами из степного Поволжья. Возможно, именно эти коллективы приняли участие в продвижении на запад, в правобережье Волги. Представленная в данной статье информация о гончарной технологии подтвердила динамику распространения елшанских гончарных традиций на запад, а также вероятность миграции неолитических коллективов из Волго-Уралья в Сурско-Мокшанское междуречье, Верхнее и Среднее Подонье [20].

Автор выражает искреннюю благодарность за помошь в работе В.Я. Кияшко, А.В. Суркову, Р.В. Смольянинову, Е.В. Долбуновой, А.Н. Мазуркевичу.

\section{СПИСОК ЛИТЕРАТУРЫ:}

1. Бобринский А.А. Гончарство Восточной Европы. Источники и методы изучения. М.: Изд-во «Наука», 1978. 272 с.

2. Бобринский А.А. Гончарная технология как объект историко-культурного изучения // Актуальные проблемы изучения древнего гончарства: кол. монограф. Самара: Изд-во СамГПУ, 1999. С. 5-109.

3. Васильева И.Н. Гончарство населения Северного Прикаспия в эпоху неолита // Вопросы археологии Поволжья. Самара: СамГПУ, 1999. С. 72-96.

4. Васильева И.Н. Ранненеолитическое гончарство Волго-Уралья (по материалам елшанской культуры) // Археология, этнография и антропология Евразии. 2011 . № 2 (46). С. 70-81.

5. Васильева И.Н. О выделении камского ареала гончарных традиций эпохи неолита // Археология, этнография и антропология Евразии. 2013. № 4 (56). C. $73-83$.

6. Васильева И.Н., Выборнов А.А. О неолитической гончарной технологии Нижнего Прикамья и времени распространения древнейших керамических традиций // Поволжская Археология. 2013. № 1. С. 60-86.

7. Васильева И.Н., Выборнов А.А. Неолитическое гончарство населения Сурско-Мокшанского между- 
речья // Самарский научный вестник. 2014. № 2(8). C. $35-53$.

8. Васильева И.Н., Выборнов А.А. Некоторые аспекты изучения неолита Марийского Поволжья // Археология и этнография Марийского края. Вопросы археологии эпохи камня и бронзы в Среднем Поволжье и Волго-Камье. Вып. 41. Йошкар-Ола: МарНИИЯЛИ. 2015. С. 68-98.

9. Васильева И.Н., Выборнов А.А. Время появления и динамика распространения неолитических керамических традиций в Поволжье // Поволжская археология. 2016. № 3 (17). С. 1-20.

10. Белановская Т.Д. Из древнейшего прошлого Нижнего Подонья: Поселение времени неолита и энеолита Ракушечный Яр. СПб.: Изд-во С.-Петербургского ун-та, 1995. 199 с.

11. Бобринский А.А., Васильева И.Н. О некоторых особенностях пластического сырья в истории гончарства // Проблемы древней истории Северного Прикаспия. Самара: Изд-во СамГПУ, 1998. С. 193-217.

12. Васильева И.Н. О выделении видов исходного пластичного сырья древнейшей керамики и их ареалах в эпоху неолита (по материалам Поволжья) // Современные подходы к изучению древней керамики в археологии. М.: Изд-во ИА РАН, 2015. С. 16-23.

13. Мазуркевич А.Н., Долбунова Е.В., Кулькова М.А. Керамические традиции в раннем неолите Восточной Европы // Российский археологический ежегодник. 2013. № 3. С. 27-109.

14. Васильева И.Н., Салугина Н.П. Лоскутный налеп // Древнее гончарство. Итоги и перспективы изучения. М.: Изд-во ИА РАН. 2010. С. 72-87.
15. Васильева И.Н., Салугина Н.П. Опыт применения зонального лоскутного налепа в реконструкции способов изготовления крупных сосудов эпохи неолита // Самарский научный вестник. 2015. № 3 (12). C. 29-36.

16. Смольянинов Р.В., Сурков А.В. Ранний неолит Верхнего Дона // Самарский научный вестник. 2014. № 3 (8). С. 161-170.

17. Сурков А.В. Неолитические памятники Среднего Похоперья. Воронеж: Изд-во ВГПУ, 2007. $121 \mathrm{c.}$

18. Спатаро М. Характеристики технологии производства керамики раннего неолита России // Caмарский научный вестник. 2015. № 3 (12). С. 142153.

19. Васильева И.Н., Выборнов А.А. Очаги/центры ранненеолитического гончарства в европейской части России // Традиции и инновации в изучении древнейшей керамики: мат-лы междунар. науч. конф., 24-27 мая 2016 года. СПб.: Изд-во ИИМК РАН, 2016. C. $45-48$.

20. Васильева И.Н. Сравнительное изучение технологии керамики «елшанского облика» Волго-Уралья и сопредельных регионов // Культурные процессы в Циркумбалтийском пространстве в раннем и среднем голоцене: докл. междунар. науч. конф., посвящ. 70-летию со дня рождения В.И. Тимофеева. Санкт-Петербург, 26-28 апреля 2017 г. СПб.: МАЭ PAH, 2017. C. 231-234.

Работа выполнена при поддержке РГНФ: проeкm № 16-11-63015.

\section{POTTERY TECHNOLOGY OF THE EARLY NEOLITHIC POPULATION PODON'YA}

\section{(C) 2017}

Vasilyeva Irina Nikolaevna, candidate of historical sciences, senior researcher of Research Department Samara State University of Social Sciences and Education (Samara, Russian Federation)

Abstract. The paper publishes the long-term study results of the Early Neolithic population pottery technology in the Lower, Middle and Upper Don Region. This research was carried out within the framework of the historical and cultural approach by the method of A.A. Bobrinsky. It was based on binocular microscopy, traceology and experiment in the form of physical modeling. 483 samples of ceramics (conditionally separate vessels) were subjected to techno-technological analysis. They originate from the cultural layers of the Rakushechny Yar camp (294) and I Razdorskaya site (4), located in the Lower Don region, as well as 14 sites of the Middle and Upper Don Region containing Karamyshev type ceramics (185). The authors give a general description of the Early Neolithic pottery of the Don region and a comparative analysis of the data on pottery technology of the Lower, Middle and Upper Don Region population. The problems of the origin and distribution of early Neolithic pottery traditions are considered, the similarities and differences in the neolithization process in the Don region and the Volga region are distinguished.

Keywords: Don; Early Neolithic; neolithization; Rakushechny Yar culture; Karamyshev culture; ceramics; pottery technology; binocular microscopy; traceology; experiment; origin of pottery; cultural traditions; culturogenesis.

УДК 902

Статья поступила в редакцию 07.07.2017

\section{ДРЕВНОСТИ КОНЦА VI - ПЕРВОЙ ПОЛОВИНЫ V ТЫС. ДО Н.Э. В ВЕРХНЕМ ПОДВИНЬИ} (C) 2017

\footnotetext{
Мазуркевич Андрей Николаевич, старший научный сотрудник, главный хранитель отдела археологии Восточной Европы и Сибири Долбунова Екатерина Владимировна, кандидат исторических наук, младший научный сотрудник отдела археологии Восточной Европы и Сибири Государственный Эрмитаж (г. Санкт-Петербург, Российская Федерация)
}

Аннотащия. Выделенная в конце 1980-х годов руднянская культура А.М. Микляевым и А.Н. Мазуркевичем рассматривалась авторами как самостоятельное культурное явление. В последнее время было открыто большое количество новых памятников с материалами, которые можно отнести к руднянской культуре 